\title{
“Trans Enough?"
}

\section{The Pressures Trans Men Negotiate in Higher Education}

\author{
D. CHASE J. CATALANO
}

\begin{abstract}
Despite increasing attention on issues raised by trans students in higher education, almost no empirical research has examined the identities and experiences of trans students as a group, or of specific subsets of trans students. In this article, I draw on interviews with twenty-five trans-male undergraduate students to explore how their experiences of coming to understand their gender identities are shaped by their experiences in higher education. I show how participants' concerns about being "trans enough" highlight contradictions within identity discourses of and about trans men, and how their narratives often rely on a medical model or "wrong body" discourse, even while students critique that model. Participants described expending significant energy navigating conflicting demands from other trans men, from other peers, and from their undergraduate institutions, in ways that often overshadowed their own desires and internal senses of identity. Institutions should support further research to explore the experiences and needs of trans men and other trans students, while implementing known best practices to become more trans-inclusive campuses.

Keywords transgender students, colleges, universities, trans men, transgender identity development
\end{abstract}

$\mathrm{H}$ igher education is in the process of being transformed by the presence of trans students (Beemyn 2003; McKinney 2005; Negrete and Purcell 2011). These students are challenging admissions policies at women's colleges (Marine 2011a; Troop 2011), are hastening the push for gender-inclusive housing (Tilsley 2010), and are raising new questions about how gender functions on college campuses in the United States (Padawer 2014; Schulman 2013). Higher education has been characterized by genderism (Hill 2003; Marine and Nicolazzo 2014), the practice of strict adherence to the gender binary in college procedures and norms. Through their visibility and voices, trans students on campus are insisting on intentional attention by faculty and administration to provide an environment in which these trans students can thrive. Hostile campus climates (Rankin and Beemyn 2011) and experiences of institutional discrimination against trans students persist (McKinney 2005).

TSQ: Transgender Studies Quarterly * Volume 2, Number 3 * August 2015

DOI 10.1215/23289252-2926399 $\quad$ C 2015 Duke University Press 
As Rob Pusch (2005) notes in his research on transgender college students, issues of misrecognition and invisibility of transgender identities "serve to reinforce a bi-gendered cultural system where one must look convincingly like their self-identified gender through hormones and surgery" (53). The search for recognition pushes trans students toward a hormonal and surgical imperative, which reinforces pathologizing of trans identities (Marine 2011b). In this article, I show how the persistence of biomedical transition narratives affects the experiences of trans men in college. I argue that the expressed desire of some of my study participants to begin biomedical transition options reflects the sometimes contradictory messages about what it means to be "trans enough."

Research and policy initiatives that focus on improving trans students' inclusion in higher education emerged relatively recently, with the first publications appearing in the early 2000s (Beemyn 2005; Beemyn, Curtis, et al. 2005; Beemyn, Domingue, et al. 2005; Beemyn and Pettit 2006). Absent from the few publications enumerating best practices of trans inclusion in higher education is empirical research supporting the efficacy of such practices, specifically, research exploring the complexities of trans students' collegiate experiences (Dugan et al. 2012). The few published empirical studies that focus on the experiences of trans students include Bilodeau 2005; Dugan et al. 2012; McKinney 2005; and Pusch 2005. This study (derived from a larger one, Catalano 2014) and others related to it are attempts to give voice to a specific trans student population — trans menbased on empirical evidence.

In this article, I first review key texts on trans men and then situate my research in relation to the literatures on trans men in higher education. I provide an overview of my methodology and outline the demographics of my participants, and then I discuss key findings about participants' insecurities about being "trans enough" and the dynamics of passing. I conclude by examining the potential influence of biomedical transition imperatives by institutions of higher education and providing suggestions for improving trans men's inclusion in higher education. I use trans or transgender to refer to participants in my research, according to each participant's self-description, and other permutations of trans man to reflect language used in a specific text.

\section{The Literature}

Since the mid-1990s, books that address female-to-male (FtM) transgender/ transsexual identity have been published in a variety of genres, including memoirs (e.g., Green 2004; Valerio 2006) and essay anthologies (e.g., Diamond 2004), and in a variety of academic disciplines such as sociology (Rubin 2003; Schilt 2010) and anthropology (Cromwell 1999). Books about biomedical and social transitions have also been written by mental health practitioners seeking to aid 
transsexual people or their families (e.g., Lev 2004). These writings have helped to resist the marginalization and silencing of trans men's existence; yet prior to the late 1990s, the dearth of empirical research specifically attending to the experiences and identities of trans men left a pronounced gap in understanding (Califia 2003; Cromwell 1999).

This literature has opened a much-needed window into the lives and experiences of trans men. Jamison Green (2004) discusses his personal transition into manhood and the legal, medical, and policy requirements of his biomedical transition process. Morty Diamond's 2004 anthology collects narratives that express nuanced perspectives of gender and juxtapose FtM narratives "alongside the stories of those who also started their life as female, but identify as something else entirely" (8). Sociologist Henry Rubin's (2003) qualitative research develops theoretical perspectives on FtM identity, embodiment, bodies, masculinities, and histories from twenty-two participants who were not undergraduate students. Kristen Schilt (2010) takes up employment as a site to examine the experiences of transgender men in the workplace, and how their experiences can illuminate complex structural inequalities based on race, gender, and sexuality. The robust research on trans men fills some of the gaps that prior research neglected (Devor 1997; Lothstein 1983; Rubin 2003; Schilt 2010), though none of this rich qualitative research focused on college students.

Jason Cromwell's work on FtMs and his critique of the "wrong body" narrative is especially apt for my research. He points out, "For many transsexuals ... their wrong body (a biophysical entity of sex), now 'corrected [by surgery],' becomes a gendered body of a woman or a man" (104). In this account, "the wrong body" is a superficial description for the misalignment between body and cultural meanings of gender ascribed to specific parts of the body. "If breasts were defined as male, transmen and FTMs would not be dysphoric about them or have them removed. Because breasts are a sign of femininity, however, chest reconstructions are requested" (Cromwell 1999: 106). He questions for whom the body is wrong and suggests that the "wrong body" language is rooted in our sex/gender binary system; it is the limitation in language "that cannot accurately hear or adequately interpret the individual experience of transness" (105). Cromwell's analysis of the failure of language to describe experiences of and needs around physical embodiment provides an entry point to consider the pressures on trans men to access biomedical transition options.

Cromwell reproduces an essential part of the medicalized narrative, however, when he asserts that most trans men have always had a childhood desire to identify as a man or with manhood. He writes, "It is the rare FTM or transman who does not know from an early age what his gender identity is" (1999: 105). The expectation that there is a shared narrative that begins in early childhood for trans 
men has been contested. Some writers have suggested that medical gatekeeping geared to the preservation of gender norms has influenced how trans men think of their gender. Prior to 2012, when my study was conducted, trans men were required to describe a "gender troubled childhood" (Spade 2003: 23) in order to receive a diagnosis of gender identity disorder and gain access to biomedical transition options. ${ }^{1}$ Trans people have employed various tactics and strategies to become recognizable to medical gatekeepers, such as constructing narratives to meet requirements that do not fully reflect their lived experiences (Califia 2003; Rubin 2003; Stone 1997). Rubin (2003) also notes the strategic utility of these narratives but argues that such narratives are also a way for trans men to make sense of themselves. Still, the persistence and consistency of narratives' citing a "wrong body" discourse seem to signal its continued influence on the construction of authenticity within trans-male communities.

Rubin (2003) notes a hierarchy based on "community standards [that] stress that hormones make the man” (9). Among Rubin's twenty-two participants who were all from urban settings and ranged from twenty-three to forty-four years old, "transitioning, at least a desire to transition, is hegemonically regarded as the truest sign of a transsexual identity" (138). The centrality of bodies in Rubin's (2003) research reveals a hierarchical structure about what it means to be "authentically transsexual" (and authentically a man), determined by use of hormones and language. Rubin's assertions are likely influenced by the fact that all but three of his participants were on testosterone at the time of the study. Whether or not Rubin or Cromwell's participants are representative of all or most trans men, their theorizing emphasized a perspective of physical bodies' being primary sites of transformation with consistent stories and trajectories. Their studies cannot tell us the degree of influence trans men may have felt to tell a certain narrative to satisfy the requirements of medical gatekeepers. Trans men who do not experience a persistent childhood desire to become (or be seen as) a boy, or do not desire any biomedical transition options, may face exclusion, be unrecognizable, or experience rejection by trans and cisgender people because they are not "really" trans. As I will discuss in this article, the historical implication of what it means to be trans enough has an impact on the participants in my research.

Literature on student affairs and higher education tends to "conflate the experiences of lesbian, gay, bisexual, transgender, and queer populations" (Dilley 2004: 113). This conflation reflects assumptions that transgender people are affiliated with broader LGBTQ communities and that transgender identities logically belong among the other identities referenced by the LGBTQ moniker, despite many scholars' contestation of both assumptions (Bilodeau 2005; Dugan et al. 2012; Marine 2011b; Pusch 2005; Stryker 2008). Susan Marine (2011b) 
similarly notes that the extant literature often conflates the experiences of trans students with LGB students, thus obscuring their unique histories and perspectives. Of the publications about trans students specifically, most consist of suggestions for policy and practice changes that would increase support services; reduce bureaucratic barriers for trans students (e.g., names and gender change); ensure that gender-segregated facilities are accessible according to self-determined gender identity; offer access to trans-specific health care, including biomedical transition options for those trans students interested; and make campuses more inclusive (Beemyn 2003, 2005; Beemyn, Curtis, et al. 2005; Beemyn, Domingue, et al. 2005; Beemyn and Pettit 2006; Sausa 2002; Bilodeau 2007; McKinney 2005). A more radical recommendation from within some of the same literature calls for the dismantling of what some researchers identify as an oppressive gender binary system and suggests a more fluid, nonbinary system for gender self-identity options (Bilodeau 2007; Bornstein 1994; Butler 1990).

\section{Methodology}

The findings presented here address one of a larger study's (Catalano 2014) overarching research questions: how are trans men's experiences of coming to understand their gender identity shaped by their experiences in higher education? Participants' reflections on their identities also connect to issues of gender expression, gender roles, definitions of masculinity, and expression of masculinity. My analysis of these trans men's narratives revealed their desire for recognition and their navigation of dynamics around embodiment and passing in college. Higher education is a site where many people explore and define their identities (Torres, Howard-Hamilton, and Cooper 2003). Collegiate settings allow for an examination of how a specific institutional context may enact oppression and diminish power of trans men as they explore their identities.

My research is based on an explicit social justice education framework (Bell 2007; Hardiman, Jackson, and Griffin 2007; Love 2010; Young 1990), which provides tools for systemic/cultural, institutional, and interpersonal analysis of power, privilege, and oppression. The study examines the impact of power structures on the lives of trans men, including the complexities of multiple social memberships and identities along with the institutional and cultural structures that perpetuate oppression. The social justice education framework is informed by scholarship from a multitude of disciplines and draws on a range of social theories (Bell 2007).

Theories of social identities are of particular relevance to this research. As Beverly Daniel Tatum describes, identity "depends in large part on who the world around me says I am," and it is complex, "shaped by individual characteristics, family dynamics, historical factors, and social and political contexts" (1997: 18). 
Tatum builds on Charles Cooley's (1922) concept of "the looking glass self," which, according to Tatum, theorizes that "other people are the mirror in which we see ourselves" (Tatum 1997: 18). Tatum also turns to Erik Erikson (1968) for a more nuanced account of how "other people are the mirror" and describes a process of identity formation that is simultaneously reflection and observation, in which the individual views their identity based on how others judge them and on typologies available to them. For the trans men in my study, the distinctions between the self and the mirror or between the individual core and the communal cultural core are complicated in ways that Erikson hardly anticipated. The narratives of the trans men in my study describe struggles to find individual and group affinity identification. Their gender expressions may not have been accurately "read" by others, and/or the trans men may not have an easily referenced gender others can understand. Trans men find themselves dealing with how to align their "inner conditions and outer circumstances" (Erikson 1968). Trans men discussed having trouble distinguishing how they view themselves and how others group them (as men, as women, as trans) because the "looking glass self" becomes a kaleidoscope or multifaceted crystal rather than a simple mirror.

I used grounded-theory methods for data collection (Charmaz 2006; Corbin and Strauss 2008; Glaser and Strauss 1967) and waited to conduct my literature review until after the completion of my coding process (Charmaz 2006). I utilized qualitative descriptive method (Sandelowski 2000) and phenomenology (Seidman 2006) for my data presentation. Based on the procedure outlined by Charmaz (2006), I conducted twenty-five in-depth, face-to-face interviews of undergraduate students enrolled at various colleges and universities in the New England region of the United States in the spring of 2010. My use of the term trans man in my call for participants attempted to include everyone with the general experience of having been assigned at birth as a female, having been socialized in female gender roles and treated as a girl, and later having come to identify as something other than a girl/woman and/or female.

Sixteen of the participants were enrolled in private four-year colleges (three at single-sex institutions), eight at large public universities, and one at a public community college. Participants' ages ranged from 18 to 52 years with a median age of approximately 22.5. The racial identities of participants were as follows: seventeen identified as White, one identified as African American/Black, and seven identified as biracial/multiracial/multiethnic. Not all participants in this study wanted to identify with trans (as a noun or as an adjective), and not all of them identified as trans men. In all cases, the words they used about their transness and gender conveyed their desires about transitioning. As will be further articulated in the next section, for these men the social components of transitioning (name, pronouns, and gender roles) were secondary to the "realness" of the body. 
My research participants described more than one "communal culture" in their accounts of interactions with their families, college administrators, faculty, peers, and the public as encountered in public restrooms, in shops, on the street, and on campus. They also described more than one "core self" in their accounts of their past selves. For some, the past self was an indefinable not-female, for others male, and for others trans - in bodies that they or others identified as previously female and as in transition toward becoming male or not female. In the three findings sections that follow, I discuss the three major themes in my data: managing expectations about being "trans enough," dynamics of passing, and the imperative of biomedical transitioning.

\section{Trans Enough: Managing Expectations of Peers and Norms}

Participants' identification with being trans was complicated by their desires for, access to, and decisions about biomedical transition. As Rubin (2003) points out, "Decisions not to transition are regarded skeptically [by other FTMs], although more leeway is given to those who want to transition but cannot due to reasons beyond their control" (138). As echoed by participant JB,

I think guys that have chosen hormones and surgery have this- not obviously not all of them, I'm not meaning to make a generalization, but there is a large sect or at least some sort of sect of [trans guy] that goes on the thought of: if you choose not to do that, and even if you're a femme boy, kind of thing, you're obviously just not trans, and you should go seek out the genderqueer community. And I think that no one can choose someone else's identity and regardless if you're trans, I think the whole point is: if you think you are trans, then you're trans.

JB points out that while it is not true of all trans communities, there are widely known opinions that those who are not interested in transition options are not "really" transgender or transsexual men. Messages of not being "trans enough" are linked to biomedical transition choices and ideas (inside and outside trans communities) about what it means to be a "real" trans man. Participants articulated messages they and/or others believed of who is trans enough, characterizing those who use testosterone and have surgeries as the most "authentic." These messages, coming from both within and outside trans communities, emanate from the pervasiveness of the wrong body narrative that equates legitimacy among trans people with biomedical transitioning. JB argued for more of a self-determination model, which many scholars also argue for (Bilodeau 2005, 2007; Catalano, McCarthy, and Shlasko 2007; Cromwell 1999; Spade 2003; Sullivan 2008). Such a self-determination model would simultaneously eliminate requirements (or 
pressures) for biomedical transition and remove barriers to biomedical transition for those who desire it.

The idea of not being trans enough was articulated by Micah in response to a question about any negative changes he may have experienced since identifying as trans:

\begin{abstract}
Negative things that have happened were definitely this idea that I wasn't trans enough. That I had to get through a lot of hurdles where I realized that it's okay to be myself, but at the beginning of that process, I was just like, "Oh my God. I'm not trans enough. People are not going to take me seriously. Oh my God." People are going to think I'm a joke and all this sort of stuff. And after a while, I actually realized that's not true, and I have every right to identify as exactly how I want to identify and nobody else can tell me different.
\end{abstract}

To be taken seriously as trans by others (regardless of self-understanding) means one must perform or embody a trans identity based on certain requirements. That is, one must be not just transgressive or ambiguously gendered or going through a phase but also en route to being a man. Within trans communities, participants reported that chronological age was less important than the length of time they had been utilizing hormones. "Transition age" was more of a factor in establishing oneself as a "legitimate" transgender or transsexual man: "In particular in the trans community, I think it's sort of this thing like, oh I'm not on hormones and everyone else is. Am I trans enough to be hanging around with these people? ... Do they accept me as one of them? So I tend to sort of stay away from the trans community" (Jackson). Participants frequently expressed concerns of legitimation, including Micah's early fears of identification and Jackson's reluctance to be involved within the trans community at his college. Thus self-determination was ignored because those not accessing hormones were seen as not having "proven" they were serious about being men, or as not having met a threshold for being trans enough to other trans men. Participants were influenced by messages they received from other trans men and cisgender people about being trans enough, and sometimes these messages trumped their self-confidence in their trans identity.

Biomedical transitioning was not the only area in which participants experienced concerns of not being trans enough. Ren disconnected from the trans community at his university because he felt their rigid notions of gender were antithetical to his trans identity. In particular, Ren's embrace of certain qualities viewed by others as "feminine" was problematic:

So when I first started identifying as trans, I was really trying to be masculine. Doing all the things that everyone's always like, "Oh, walk this way." And like, "Sit 
this way and wear this clothing." And then I was just like, "Well yeah, but why do I have to be one specific - one type of guy?" Just because I'm trans? It's like, so you're allowed to be an effeminate guy [if you're not trans], but if I am, it just means that I'm not being trans good enough. And I feel like [my university] — a lot of the [my university's] trans community is very much like that, at least from what I've found.

Contrary to some popular beliefs about trans identities as transgressive gender expressions, Ren's experience indicates that some university communities enforced gender-normative expressions among trans students. Although some would argue that the alignment with normative masculinity is meant to help trans men pass as men, it simultaneously reasserts the privileging of gender normativity and trans oppression (Bilodeau 2005, 2007; Catalano, McCarthy, and Shlasko 2007). Ren's experience highlights the impact of trans oppression (through the assertion of gender-conforming expectations), which led to his alienation from the trans community on his campus. Participants describe the importance of normative masculinities as a valid (and necessary) embodiment for trans men, as these masculinities set up distinctions of authenticity and may have implications for how trans men locate and experience other men in college communities. Judgments about "authenticity" within trans men's communities replicate ways in which oppression of trans men evolves into internalized oppression through the concept of transnormativity (LeBlanc 2010; Warner 1999).

While many participants felt pressured to legitimate their core maleness, a few participants indexed "trans" as subverting the gender binary by embodying a liminal gender. For Riley, his alignment with stereotypical masculinity seemed incongruent with his sense of transness:

The way I see masculinity or I guess it's not something I can. . . . It's just kind of what you feel. It's like a casual kind of thing. . . So yeah, I kind of fall into a lot of male stereotypes, like my room is really messy, and I don't do laundry until I absolutely have to, and I watch football and all that stuff. So yeah, I'd call myself [laughs] pretty stereotypical. I'm supposed to be shaking the gender binary or what have you, and I guess I'm not doing a very good job of that ... I feel like as someone who is aware of the gender spectrum, I should do my part to try and educate other people and... I've kind of not. I watched football instead.

Riley seemed disappointed in himself because his gender presentation and traits were "too normatively masculine," and he failed at "shaking the gender binary." For most, however, "trans enough" means crossing the gender binary, not living between two genders. For example, Ren felt ostracized from his university's trans 
community because his gender expression was too transgressive. Riley's understanding of "authenticity" of transness reflects a trans politics focused on the idea that it is better to be more transgressive and to resist the invisibility that comes with passing, whereas Ren internalized messages implying that the authenticity of transness is about replication of gender normativity through transition, masculine embodiment, and passing.

Another factor that influenced perceptions of being "trans enough" (in the normative sense) was connected to messages about what types of biomedical transition options the trans students in my research would access. Although the standards of care operative at the time of my study (Meyer et al. 2002) acknowledged the possibility that not all FtMs consider genital surgery, there is a "focus on genital surgery as the marker of the 'realness' of gender ... [and a] drive for 'wholeness' on the part of the transsexual, a drive that is supported and reified through interactions with medical and psychological institutions" (Schilt and Waszkiewicz 2006: 6). The assertion that "realness" requires genital surgery came up in numerous participants' responses, regardless of whether they identified as a man. Robert aptly characterized how the biomedical transition process made being trans "real": "When I do the medical stuff, then it's gonna be real." Even for participants who desired to conform to the gender binary, the standard route to biomedical transition was a source of stress because of the difficulty of accessing and paying for transition procedures and services, compounded by limited campus resources. $^{2}$

The tensions within these participants' campus-based trans communities about passing and embodiment versus transgressing gender norms push aside much-needed conversations about limited access to biomedical transition resources (for those interested) and the oppressive institutional structures that make existing in a gender-liminal state (for those interested) relatively untenable. Instead, conflicts over the authenticity of transness center on expectations of whether one is "trans enough," based on passing or looking masculine. For those who do not experience their transness as a transgressive gender expression, passing as trans enough only compels them toward biomedical transition. These conflicting positions distract from the structural issues trans students experience and put pressure on those students who might not otherwise take hormones and/ or pursue surgery.

\section{Passing}

Participants struggled to make meaning of their visibility as men and invisibility as trans (for those who passed), or their invisibility as men (for those who did not pass). Passing and (in)visibility had implications for their ability to connect with cisgender men in what felt like a forced affinity, since they lacked familiarity with 
the norms, social cues, behaviors, and other dynamics of this group. Awareness of one's own passing is a mode of understanding how others view one in the "looking glass." The looking glass highlights the external social world of the gender binary, but because the world does not align with self-perceptions, it also presents a muddled image for trans men. Gender identities are based on individual selfperceptions but are also simultaneously impacted by others' views (West and Fenstermaker 1995; West and Zimmerman 1987). Jack felt odd about how the others group him with men, based on his appearance: "Most people just receive me as masculine, as a man, and they wouldn't separate me from other men at all, which is so strange. . . To really get the feeling that I'm just like everybody else, and I am, sure. But I've always felt on the outside, so I have feeling like I'm separate." Some trans men desired to have their transness visible, and others desired to place their trans identity firmly in their past, even if they were uncertain how they wanted to be identified by others. The body is the site for FtMs to claim manhood (Rubin 2003), but perceptions of their bodies can also make their transness invisible.

Some trans men discussed feeling able to see in cisgender men a physical form they hope to achieve, but for those uninterested in passing, there may be few models available: "I don't really see myself as a very masculine person. I don't know masculinity and femininity, I have issues with [them]" (Ben). Regardless of an ability to clearly express their gender in a way that felt comfortable or authentic to their core gender identity, participants continually managed others' perceptions of their gender: "Yeah, I guess how safe I feel directly correlates to how genderqueer I'm willing to look" (Sal).

Participants described the experience of passing as cisgender men on campus in contradictory terms. On one hand, passing was seen as an achievement, on the other, passing resulted in silencing and invisibility. Participants described their relationships with masculinity as sometimes uncertain, sometimes aligned, and sometimes as a compromise gender expression. These varying relationships only exacerbated their complicated opinions about passing. In many of the participants' accounts, passing provided opportunities for trans men to become more comfortable in their appearance as men. Joshua discussed how he tried to present his body and its movements in ways that were imitations of cisgender men: "Because, for me, the whole point of transitioning was to be able to be authentic and to just be myself, and I think pretty early on I spent a lot of time trying to fit a mold of what I thought a guy was supposed to be.... You know, walk a certain way. Talk a certain way. Body posture. Whatever...” For Joshua, his early efforts at normative masculine embodiment trumped his desire to simply be authentically himself.

The dilemmas posed by passing emerged in the language participants used to describe their current gender expression. For example, some participants were 
mostly focused on not being seen as women, even if they did not identify as a man and did not reject their female past. Tucker, for example, described his gender expression as "masculine to androgynous. I tend to err on the side of masculine, but I like androgynous clothing and I like androgynous looks. I'm more interested in removing obvious gender markers than I am in creating them." JB described his desire to be seen in a way that was accurate, but he believed others saw him through their own perceptions of gender. He noted, "I want to feel queer, but I think I just pass as an Abercrombie boy." JB felt powerless to influence how others understand his internal feelings of "queerness" from his outward embodiment, as normative for young (white) men of his age. Participants' gender expressions were rooted in a presentation of the body that aligned with social and cultural expectations of masculinity. For those willing to compromise their desired gender expression for the sake of readability as men, passing as a man is the only way for participants to be read as not-women, given naturalized assumptions about the gender binary (there are only men and women).

Because passing on campus causes transness to become invisible, some trans men in this study experienced forced or desired reabsorption into the gender binary as men. Here personal history becomes important to current identity. Cisgender men have a long personal history as boys/men, with role models, and the experiences of learning the rules through gender enforcement (Harro 2000); trans men's personal histories do not include such opportunities. Trans men are left with stereotypes and assumptions about the world of "Guyland" (Kimmel 2008), and there are few supports available on most college campuses to help them navigate their new role in the gender binary (Marine and Nicolazzo 2014). In a consistent pattern, participants described a discomfort or caution with cisgender men and with the category of "man." For some, the experience of being categorized with cisgender men raised the question of whether their masculine postures reified normative masculinity, which was troubling to them because of their ideological connections to feminism and other ideologies (Hansbury 2004). For example, Sal describes his discomfort with balancing recognition of his whole self (past and present genders) and others' recognition of his current gender:

A lot of times [with women] it's like, "Oh well, you were born a girl, you must be more sensitive, right?" ... It's kind of ungendering. It's like, "Oh well, because you were born this way you must be able to identify with me in these ways," which is weird because I've also found a lot more validation from girl people because some of my friends can — who are girls can see me as different from them and therefore, as a guy. Whereas guy friends see me as not the same as them and therefore, not a guy. So I'm like, I don't know. 
The expectations that he would be more "sensitive" and less stereotypically masculine in his behaviors served to "ungender" Sal's masculine embodiment. He also experienced unfair expectations from the group of people (women, or "girl people" as he called them) who were most likely to provide him with gender validation because his gender stood in contrast to their gender as women.

Choosing to come out as trans, or to risk losing the ability to pass by revealing a divergent gender history, can endanger one's claim to being a "real man" or thrust one into a specific role based on one's past as female. Brandon noted, "In some cases you come out to people and suddenly they're like, 'Oh you're not a man anymore.” They initially read him as a cisgender man, and they ignore his bodily signifier when he comes out as trans. The rejection Brandon describes is a form of misrecognition that impedes his passing or self-identification. As Jay Prosser notes, "for in coming out and staking a claim to representation, the transsexual undoes the realness that is the conventional goal of transition" (1998: 11).

Participants in this study described numerous fears and uncertainties that influenced their expression of masculinity, many of which revolved around how their bodies were read and their comfort with their bodies. Their visibility was fraught with uncertainty that arose from the (in)visibility of transness that sometimes competed with their self-identification. Cisgender college men were not an appropriate group for comparison for participants because trans men did not experience (for better or worse) the same gender socialization. For those participants who were out about their trans identity, they had to endure cisgender peers' gender-essentialist assumptions or experience rejection of their current gender identity as men. These disconnects were subtle and tended to push trans men toward biomedical transition options and silence of their pasts.

\section{The Biomedical Transition Imperative}

Another factor that influenced participant concerns about authenticity were tensions within their campus trans communities about who falls under the "transgender umbrella" as it is connected to embodiment. Those who accessed biomedical transition services became more aligned with gender binary notions and internalized the medical model (Davidson 2007), and thus they were viewed as more legitimately trans than those who did not pursue gender-related body modification. Although access to medical care was seen as validating one's transness, it was not always easy to do, even when colleges provided avenues for doing so. For Robert, accessing biomedical transition options was not as simple as he imagined: "As I'm getting ready for surgery, like mentally for that, [I am] realizing things like: you can want something with absolutely all of your being and still be absolutely terrified, which is sometimes hard to explain to people.” As noted by 
Katrina Roen (2001: 504), "it is not uncommon for trans communities to operate within the opposite hierarchy, valuing passing and ostracizing those trans people who do not seem to work hard enough at passing." Ren discusses how on his campus the trans and queer reinforce gender normativity: "It's a very limiting kind of community and we have . . . almost everyone has transitioned or is planning to."

Conflicts in trans communities over distinctions of embodiment indicate how trans men experience marginalization, particularly when they align with assumptions of what it means to be a man. Types of body modification unrelated to transition (e.g., rhinoplasty and penile enlargement) do not require psychological oversight and approval (Wilchins 1997; Spade 2003). But trans people must legitimate their claims, even when those claims serve to reinforce the hegemony of the gender binary and cast doubt on those who wish to claim trans identity but refuse to conform to the medical model and gender norms (Stone 1997). Shawn, who was uncertain about when or if he would pursue biomedical transition options, shares his struggle to articulate his self-perception: "I can't look in the mirror and identify with that name [my birth name], but I can see myself as Shawn." Without the masculinizing impact of hormones or surgeries, Shawn has to legitimate his identification as Shawn and not the gender associated with his birth name.

\section{Discussion and Suggestions for Improving Practice}

Participants in my research described their search for balance between internal confidence and external recognition and pressures. For the most part, participants struggled with self-confidence in their trans identification because of the reification of hegemonic notions of gender from within and outside their trans community, mostly expectations of coherent and normative masculine embodiment; a few participants also articulated the opposite pressure to perform gender transgression and incoherence from some trans communities. What to do with or to their bodies becomes central to these students' genders and identities, as well as their access point to acceptance. James Messerschmidt (2009: 87) posited that "the body is a participant in shaping and generating social practice, and consequently, it is impossible to consider human agency without taking embodied gender into account." To be a full participant in social practice, with few exceptions trans men in this study usually characterized "trans enough" as the desire and ability to access biomedical transition services (hormones and/or chest reconstruction).

The worlds of trans men in college were generally bounded by their immediate campus environment, which depended on enrollment size, friends, and visible trans communities. These structural realities influenced their abilities to pass, to embody masculinity, and to interact with cisgender men in homo-social 
communities. As noted in the findings, higher education as an institution is enmeshed in systemic processes that exist beyond the boundaries of any specific campus. The life experiences of these trans students cause their identities to shift and change, whether they understand these shifts as only external or as also encompassing shifts in their understanding of themselves. In my study, many trans students' lived bodily experience of passing or not passing became central to their gender identities, overshadowing their other feelings about their internal sense of gender. Their focus on embodiment, which echoes Rubin's (2003) research, was reinforced by people and dynamics within a higher education context and by the Harry Benjamin International Gender Dysphoria Association's standards of care, version 6 (now World Professional Association for Gender Health [WPATH]), which was in use at the time the data were collected. In order to access biomedical transition options, they had to advocate for themselves tirelessly, and in narratives intelligible to the medical model (Meyer et al. 2001). Some participants had internalized the notion that people who do not conform to the gender binary need to biomedically transition. That imperative was reinforced by structures they encountered in higher education.

Trans men are not monolithic in their relation to gender. For trans men, there is no single approach to being a man, as demonstrated by the participants in my study, and that signals a need for higher education professionals to create more inclusive campuses for a variety of trans men. The focus on bodies and embodiment in these participants' descriptions of identity and experience indicates that messages trans men receive emphasize material biomedical options as a primary path to recognition. Policies created by administrators that set the parameters of trans men's legibility can affirm or disavow students' identities. Creating change on a college or university campus is a dynamic process, not a simple checklist. Based on these findings, I offer two suggestions to attend to issues of support for trans men (and possibly all trans students) in higher education: adopt known best practices, and put resources toward research and assessment. The complexity of this study's findings revealed that there is no "one size fits all" model for supporting trans inclusion and agency, and sometimes those we seek to support may be discouraged, silenced, or marginalized by our attempts at inclusion. Findings from the theme "trans enough" expose the pressure to biomedically transition that trans men in college feel; this should prompt faculty and administrators at institutions that have policies and practices requiring medical verification to question the utility and fairness of those requirements. The newest version of the WPATH standards of care allow for a lower threshold of medical gatekeeping; institutions of higher education should review policies to ensure alignment with these new guidelines (Coleman et al. 2012). 


\section{Conclusion}

Because this was a small study focused on students in New England, slightly more than half (64 percent) of whom attended private institutions, questions remain about how central issues of passing and embodiment are for trans men in higher education more broadly, and how that may manifest in different geographies and institutions. Regardless, participants reported few campus-designated opportunities to explore their internalized questions about attaining "realness" or being trans enough. More opportunities are needed for trans students to explore their own conceptions of their gender. Current limitations to programming for-as opposed to about - trans individuals and communities have been noted by other researchers (Marine and Nicolazzo 2014). Further, there need to be spaces where cisgender people examine their own understanding of trans identities, to ensure they are not replicating genderism or pathologizing trans students more broadly. All members of a collegiate institution need to educate themselves beyond the assumptions of biomedical transition and refrain from contributing to enforcing a medical-model understanding of transness. In summary, this study points to three specific improvements to supporting trans men in higher education: evaluating current policies and practices for adherence to updated standards of care requirements; providing ample space, time, and opportunity for individual and group exploration of trans identities and "realness"; and assessing whether positive developments in insurance coverage for transition-related health services (hormones, surgeries) promote biomedical transition as the only way to achieve "real" manhood.

If a trans man in college is unnecessarily diverted from focusing on cocurricular involvement because he is primarily worried about whether he is viewed as a man, then he is unable to develop intellectually and socially with his peers (Pascarella and Terenzini 2005). If trans men spend most of their time worried that they are not trans enough because they pass as too normatively gendered or not normatively gendered enough, then their focus is not on selfexploration and college success but on others' perceptions of them. Trans men in this study understand their legibility as men and/or the ability to pass as being tied up in embodiment. As much as we need to theorize the possibilities of trans identities beyond the medical model, colleges and universities must also attend to the limitations of the lived day-to-day experience of trans students' struggling to survive their college or university administrative processes and resources. The real and central concern for the trans men in this research is the lack of space, time, and effort put forth by institutions to actually understand their needs. Only through continued support for, and attention to, trans men and their needs can we create college campuses that are truly trans inclusive. 
D. Chase J. Catalano is an assistant professor at Western Illinois University in the College Student Personnel Program.

\section{Notes}

1. The current WPATH standards of care, version 7 (SOCv7; Coleman et al. 2012), requires less rigid requirements for access to biomedical transition options, but at the time of this research, SOCv7 was still two years from publication.

2. There has been a significant increase in access to biomedical transition options for college students since the time of my data collection. Currently, sixty-two colleges and universities have trans-inclusive coverage for student health insurance plans (Campus Pride Index).

\section{References}

Beemyn, Brett. 2003. "Serving the Needs of Transgender College Students." Journal of Gay and Lesbian Issues in Higher Education 1, no. 1: 33-50.

Beemyn, Brett Genny. 2005. "Trans on Campus: Measuring and Improving the Climate for Transgender Students." On Campus with Women 34, no. 3. www.aacu.org/ocww /volume34_33/feature.cfm?section=32.

Beemyn, Brett, Billy Curtis, et al. 2005. “Transgender Issues on College Campuses." In Gender Identity and Sexual Orientation: Research, Policy, and Personal Perspectives, edited by R. L. Sanlo, 49-6o. San Francisco, CA: Jossey-Bass.

Beemyn, Brett, Andrea Domingue, et al. 2005. "Suggested Steps to Make Campuses More TransInclusive." Journal of Gay and Lesbian Issues in Education 3, no. 1: 89-94.

Beemyn, Brett G., and Jessica Pettit. 2006. "How Have Trans-Inclusive Non-Discrimination Policies Changed Institutions?" GLBT Campus Matters 3, no. 1: 6-7.

Bell, Lee Ann. 2007. "Theoretical Foundations for Social Justice Education." In Teaching for Diversity and Social Justice, edited by Maurianne Adams, Lee Anne Bell, and Pat Griffin, 1-14. 2nd ed. New York: Routledge.

Bilodeau, Brent. 2005. "Beyond the Gender Binary: A Case Study of Two Transgender Students at a Midwestern Research University." Journal of Gay and Lesbian Issues in Education 3, no. 1: 29-44.

- 2007. "Genderism: Transgender Students, Binary Systems, and Higher Education." PhD diss., Michigan State University.

Bornstein, Kate. 1994. Gender Outlaw: On Men, Women, and the Rest of Us. New York: First Vintage.

Butler, Judith. 1990. Gender Trouble: Feminism and the Subversion of Identity. New York: Routledge.

Califia, Patrick. 2003. Sex Changes: Transgender Politics. 2nd ed. San Francisco: Cleis.

Campus Pride Index. "Colleges and Universities That Cover Transition-Related Medical Expenses under Student Health Insurance." www.campuspride.org/tpc-student-health-insurance/ (accessed February 18, 2015).

Catalano, Chase, Linda McCarthy, and Davey Shlasko. 2007. "Transgender Oppression." In Teaching for Diversity and Social Justice, edited by Maurianne Adams, Lee Anne Bell, and Pat Griffin, 219-45. 2nd ed. New York: Routledge. 
Catalano, D. Chase J. 2014. "Welcome to Guyland: The Experiences of Trans ${ }^{\star}$ Men in College." EdD diss., University of Massachusetts Amherst.

Charmaz, Kathy. 2006. Constructing Grounded Theory: A Practical Guide through Qualitative Analysis. Los Angeles: Sage.

Coleman, Eli, et al. 2012. "Standards of Care for the Health of Transsexual, Transgender, and Gender-Nonconforming People, Version 7.” International Journal of Transgenderism 13, no. 4: 165-232.

Cooley, Charles. 1922. Human Nature and Social Order. New York: Scribner.

Corbin, Juliet, and Anslem L. Strauss. 2008. Basics of Qualitative Research: Techniques and Procedures for Developing Grounded Theory. 3rd ed. Los Angeles: Sage.

Cromwell, Jason. 1999. Transmen and FTMs: Identities, Bodies, Genders, and Sexualities. Urbana: University of Illinois Press.

Davidson, Megan. 2007. "Seeking Refuge under the Umbrella: Inclusion, Exclusion, and Organizing within the Category Transgender." Sexuality Research and Social Policy 4, no. 4: $60-80$.

Devor, Holly. 1997. FTM: Female-to-Male Transsexuals in Society. Bloomington: Indiana University Press.

Diamond, Morty. 2004. From the Inside Out: Radical Gender Transformation, FTM, and Beyond. San Francisco: Manic D. Press.

Dilley, Patrick. 2004. "LGBTQ Research in Higher Education: A Review of Journal Articles, 20002003." Journal of Gay and Lesbian Issues in Education 2, no. 2: 105-15.

Dugan, John P., Michelle L. Kusel, and Dawn M. Simounet. 2012. “Transgender College Students: An Exploratory Study of Perceptions, Engagement, and Educational Outcomes.” Journal of College Student Development 53, no. 5: 719-36.

Erikson, Erik. 1968. Identity, Youth, and Crisis. New York: Norton.

Glaser, Barney G., and Anslem L. Strauss. 1967. The Discovery of Grounded Theory: Strategies for Qualitative Research. Chicago: Aldine.

Green, Jamison. 2004. Becoming a Visible Man. Nashville, TN: Vanderbilt University Press.

Hansbury, Griffin. 2004. "Sexual TNT: A Transman Tells the Truth about Testosterone.” Journal of Gay and Lesbian Psychotherapy 8, nos. 1-2: 7-18.

Harro, Bobbie. 2000. “The Cycle of Socialization.” In Readings for Diversity and Social Justice, edited by Maurianne Adams, et al., 45-58. 2nd ed. New York: Routledge.

Hardiman, Rita, Bailey Jackson, and Pat Griffin. 2007. "Conceptual Foundations for Social Justice Courses.” In Teaching for Diversity and Social Justice, edited by Maurianne Adams, Lee Anne Bell, and Pat Griffin, 35-66. 2nd ed. New York: Routledge.

Hill, Darryl B. 2003. "Genderism, Transphobia, and Gender Bashing: A Framework for Interpreting Anti-Transgender Violence." In Understanding and Dealing with Violence: A Multicultural Approach, edited by B. C. Wallace and R. T. Carter, 113-36. Thousand Oaks, CA: Sage.

Kimmel, Michael. 2008. Guyland: The Perilous World Where Boys Become Men. New York: HarperCollins.

LeBlanc, Fred Joseph. 2010. "Unqueering Transgender? A Queer Geography of Transnormativity in Two Online Communities." MA thesis, Victoria University of Wellington.

Lev, Arlene Istar. 2004. Transgender Emergence: Therapeutic Guidelines for Working with GenderVariant People and Their Families. Binghamton, NY: Haworth Clinical Practice Press.

Lothstein, Leslie M. 1983. Female-to-Male Transsexualism. Boston: Routledge. 
Love, Barbara J. 2010. “Developing a Liberatory Consciousness.” In Readings for Diversity and Social Justice, edited by Maurianne Adams, et al., 599-603. 2nd ed. New York: Routledge.

Marine, Susan B. 2011a. “'Our College Is Changing': Women's College Student Affairs Administrators and Transgender Students." Journal of Homosexuality 58, no. 9: 1165-86.

- 2011b. "Stonewall's Legacy: Bisexual, Gay, Lesbian, and Transgender Students in Higher Education.” ASHE Higher Education Report, vol. 37, no. 4. San Francisco: Jossey-Bass.

Marine, Susan B., and Z Nicolazzo. 2014. "Names That Matter: Exploring the Tensions of Campus LGBTQ Centers and Trans* Inclusion.” Journal of Diversity in Higher Education 7, no. 4: 265-81.

Messerschmidt, James W. 2009. "Goodbye to the Sex-Gender Distinction, Hello to Embodied Gender." In Sex, Gender, and Sexuality: The New Basics, edited by A. L. Ferber, K. Holcomb, and T. Wentling, 71-88. New York: Oxford University Press.

Meyer, Walter, III, et al. 2001. “The Harry Benjamin International Gender Dysphoria Association's Standards of Care for Gender Identity Disorders, Sixth Version.” Journal of Psychology and Human Sexuality 13, no. 1: 1-30.

McKinney, Jeffrey S. 2005. "On the Margins: A Study of the Experiences of Transgender College Students." Journal of Gay and Lesbian Issues in Education 3, no. 1: 63-75.

Negrete, Nicholas A., and Christopher Purcell. 2011. "Engaging Sexual Orientation and Gender Diversity in Multicultural Student Services." In Multicultural Student Services on Campus: Building Bridges, Re-visioning Community, edited by D. A. Stewart, 81-93. Sterling, VA: Stylus.

Padawer, Ruth. 2014. "When Women Become Men at Wellesley." New York Times, October 15. www.nytimes.com/2014/10/19/magazine/when-women-become-men-at-wellesley-college .html.

Pascarella, Ernest T., and Patrick T. Terenzini. 2005. How College Affects Students: A Third Decade of Research. Vol. 2. San Francisco: Jossey-Bass.

Prosser, Jay. 1998. Second Skins: The Body Narratives of Transsexuality. New York: Columbia University Press.

Pusch, Rob S. 2005. "Objects of Curiosity: Transgender College Students' Perceptions of the Reactions of Others." Journal of Gay and Lesbian Issues in Education 3, no. 1: 45-61.

Rankin, Susan, and Genny Beemyn. 2011. The Lives of Transgender People. New York: Columbia University Press.

Roen, Katrina. 2001. "Transgender Theory and Embodiment: The Risk of Racial Marginalization.” Journal of Gender Studies 10, no. 3: 253-63.

Rubin, Henry. 2003. Self-Made Men: Identity and Embodiment among Transsexual Men. Nashville, TN: Vanderbilt University Press.

Sandelowski, Margarete. 200o. "Whatever Happened to Qualitative Description?" Research in Nursing and Health 23, no. 4: 334-40.

Sausa, Lydia A. 2002. "Updating College and University Campus Policies: Meeting the Needs of Trans Students, Staff, and Faculty." In Addressing Homophobia and Heterosexism on College Campuses, edited by E. P. Cramer, 43-55. Binghamton, NY: Harrington Park.

Schilt, Kristen. 2010. Just One of the Guys: Transgender Men and the Persistence of Gender Inequality. Chicago: University of Chicago Press.

Schilt, Kristen, and Elroi Waszkiewicz. 2006. “I Feel So Much More in My Body': Challenging the Significance of the Penis in Transsexual Men's Bodies.” Paper presented at the annual meeting of the American Sociological Association, Montreal, Canada, August 13. 
Schulman, Michael. 2013. "Generation LGBTQIA.” New York Times, January 9. www.nytimes .com/2013/2001/2010/fashion/generation-lgbtqia.html?pagewanted=all\&_r=2010\&page wanted $=$ print.

Seidman, Irving. 2006. Interviewing as Qualitative Research: A Guide for Researchers in Education and the Social Sciences. 3rd ed. New York: Teachers College Press.

Spade, Dean. 2003. "Resisting Medicine, Re/modeling Gender.” Berkeley Women's Law Journal 18, no. 1: 15-37.

Stone, Sandy. 1997. “The Empire Strikes Back: A Posttranssexual Manifesto.” In Writing on the Body: Female Embodiment and Feminist Theory, edited by Katie Conboy, Nadia Medina, and Sarah Stanbury, 337-59. New York: Columbia University Press.

Stryker, Susan. 2008. Transgender History. Berkeley, CA: Seal Press.

Sullivan, Nikki. 2008. “The Role of Medicine in the (Trans)Formation of Wrong Bodies." Body and Society 14, no. 1: 105-16.

Tatum, Beverly Daniel. 1997. "Why Are All the Black Kids Sitting Together in the Cafeteria?" and Other Conversations about Race. New York: Basic Books.

Tilsley, Alexandra. 2010. "New Policies Accommodate Transgender Students." Chronicle of Higher Education, June 27. www.chronicle.com/article/Colleges-Rewrite-Rules-to/66046/.

Torres, Vasti, Mary F. Howard-Hamilton, and Diane L. Cooper. 2003. Identity Development of Diverse Populations: Implications for Teaching and Administration in Higher Education. ASHE-ERIC Higher Education Report, vol. 29, no. 6. Hoboken, NJ: Wiley.

Troop, Don. 2011. "Women's University to Reconsider Hard Line on Transgender Students." Chronicle of Higher Education, October 23. www.chronicle.com/article/Womens -University-to/129490.

Valerio, Max Wolf. 2006. The Testosterone Files: My Hormonal and Social Transformation from Female to Male. Emeryville, CA: Seal Press.

Warner, Michael. 1999. The Trouble with Normal: Sex, Politics, and the Ethics of Queer Life. Cambridge, MA: Harvard University Press.

West, Candace, and Sarah Fenstermaker. 1995. "Doing Difference." Gender and Society 9, no. 1: $8-37$.

West, Candace, and Don H. Zimmerman. 1987. “Doing Gender.” Gender and Society 1, no. 2: 125-51.

Wilchins, Rikki A. 1997. Read My Lips: Sexual Subversion and the End of Gender. Ithaca, NY: Firebrand.

Young, Iris Marion. 1990. Justice and the Politics of Difference. Princeton, NJ: Princeton University Press. 